\title{
Eksplorasi Loyalitas Millennial Terhadap Brand Apple. Prestige or Needs?
}

\author{
Ni Putu Ari Krismajayanti ${ }^{1}$, Gede Sri Darma ${ }^{2}$ \\ ${ }^{1,2}$ Universitas Pendidikan Nasional \\ E-mail: 19arikrismajayanti@gmail.com, ${ }^{2}$ sridarma@undiknas.ac.id
}

\begin{abstract}
Industrial Revolution 4.0 brought changes and developments in consumer behavior today. The emergance of disruptive innovation such as digital economics, artificial intelligence, big data, robotics and so on. As disruption happened, telecommunication industry is the main key. Competition in the telecommunications industry becomes strict, encouraging smartphone product to continue to grow to compete in market share. Apple.inc, one of the giant companies from Cupertino, California, is in the spotlight. Apple's smartphone, namely iPhone can survive and becomes a company that has a good brand image for consumers, especially millennials or $Y$ generation, who currently dominate the market. This study aims to determine millennial loyalty in using iPhone products. By using qualitative research methods and triangulation techniques, this study describes in detail the problem phenomena that currently occur. In this study, millennials use iPhones because following the trends, to be appreciated by its environment, one of the examples by utilizing social media and being loyal because of the security and the convenience. Millennials are also willing to save in order to buy something based on wants and needs. However, a limitation and barrier for millennials in being loyal to the iPhone is the price. This research is expected to provide information for companies related to consumer behavior in the era of the industrial revolution 4.0.
\end{abstract}

Keywords: Revolusi Industri 4.0, Consumer Behavior 4.0, Human Needs, Consumer Loyalty.

\begin{abstract}
ABSTRAK
Era Revolusi Industri 4.0 membawa perubahan dan perkembangan dalam perilaku konsumen saat ini. Kemunculan teknologi yang canggih yang disebut dengan disruptive innovation seperti pola ekonomi secara digital, artificial intelligence, big data, robotic dan lain sebagainya. Alat telekomunikasi merupakan sarana dan penunjang dalam era disrupsi. Persaingan di industri telekomunikasi yang sangat ketat, mendorong produsen produk smartphone untuk terus berkembang bersaing dalam pangsa pasar. Apple.inc salah satu perusahaan raksasa dari Cupertino, California menjadi sorotan. Smartphone Apple yaitu iPhone memiliki value tersendiri untuk dapat bertahan sehingga menjadi perusahaan yang memiliki brand image baik bagi konsumen khususnya milenial atau generasi Y yang saat ini menguasai pasar. Penelitian ini memiliki tujuan untuk mengetahui loyalitas milenial dalam menggunakan produk iPhone. Dengan menggunakan metode penelitian kualitatif dan teknik triangulasi, penelitian ini menjelaskan secara detail fenomena masalah yang saat ini kerap terjadi. Dalam penemuan, milenial menggunakan iPhone karena ingin mengikuti perkembangan trend, untuk dapat dihargai oleh lingkungan sekitar salah satunya dengan memanfaatkan media sosial dan menjadi loyal karena keamanan dan kenyamanan yang ditawarkan. Milenial juga rela menabung demi membeli sesuatu yang diinginkan. Namun dalam penemuan, harga masih menjadi batasan dan penghalang bagi milenial dalam loyal terhadap iPhone. Penelitian ini diharapkan memberikan informasi untuk perusahaan terkait perilaku konsumen di era revolusi industri 4.0.
\end{abstract}

Kata Kunci: Revolusi Industri 4.0, Perilaku Konsumen 4.0, Kebutuhan Manusia, Loyalitas Konsumen. 


\section{PENDAHULUAN}

\section{Latar Belakang}

Era Revolusi Industri 4.0 membawa perubahan dan perkembangan dalam perilaku konsumen saat ini. Kemunculan teknologi yang canggih yang disebut dengan disruptive innovation seperti pola ekonomi secara digital, artificial intelligence, big data, robotic dan lain sebagainya (Tata Rini, 2019). Dengan berkembangnya hal ini, menuntut perusahaan untuk bersaing secara kompetitif untuk membangun, menjaga dan mempertahankan komitmen dan loyalitas pelanggan. Saat ini persaingan suatu perusahaan untuk menarik perhatian pelanggan belum terfokus pada produk fungsional seperti penggunaan produk, akan tetapi saat ini produk sangat terkait dengan brand yang dapat memberikan nilai tersendiri untuk penggunaannya, maka diketahui peran merek sudah mengalami perkembangan dan menjadi aset penting perusahaan. Company Brand disebut sebut sebagai aset bernilai tinggi.

Alat telekomunikasi salah satunya yang merupakan sarana dan penunjang dalam era disrupsi ini. Bukan hanya sekedar berkomunikasi, kini dapat digunakan pula untuk mendapatkan berbagai informasi secara cepat. Salah satu perusahaan raksasa bergerak dalam bidang teknologi multinasional yang berpusat di Cupertino, California. Apple.inc yang didirikan oleh Steve Jobs, Steve Wozniak dan Ronald Wayne awalnya merupakan suatu perusahaan komputer yang disebut Personal Computer (PC). Pada tahun 2007, munculah inovasi Apple.inc yaitu smartphone bernama iPhone yang menuai kesuksesan perusahaan dan mengalami lonjakan penjualan (Gilang Irwan, 2020). Apple.inc kini menggambarkan Apple sebagai "Mobile Devices Company" - the largest one in the world. Selama bertahun-tahun, salah satu lini produk apple yaitu iPhone telah menjadi kemasan utama dalam penjualan di seluruh dunia.

Berdasarkan data dari International Data Corporation (2018) menunjukkan bahwa produk Apple yaitu iPhone termasuk di antara 5 produk paling banyak terjual di dunia. Bersaing yang lain seperti Samsung Electronics, Huawei Technologies, Xiaomi, Oppo dan lain sebagainya. Apple menjual produk dengan target konsumen menengah - keatas di Indonesia, Apple dikenal sebagai perusahaan penjual brand yang menciptakan produk yang memiliki prestige value. Meskipun dengan harga yang relatif mahal tetapi tidak menyurutkan niat milenial untuk tidak membeli dan menggunakannya. Hal ini membuktikan bahwa faktor psikologis juga mampu menjadi faktor utama bagi konsumen dalam membeli suatu produk (Ferrinadewi, 2016).

Era disrupsi juga membawa perubahan pada budaya baru di kehidupan masyarakat yaitu budaya konsumtif (Ohy, G., Kawung, E. J., \& Zakarias, 2020). Konsumsi sudah berubah menjadi suatu tanda kelas, gaya dan simbol status sosial yang mencerminkan dari gaya hidup (Mahyuddin, 2017). Tak usah dipungkiri, masyarakat kini lebih fokus pada kesenangan agar merasa nyaman dan diakui eksistensinya. Bahkan gaya hidup hedonis juga melekat dalam mengkonsumsi suatu produk, menjadi budaya baru yang seakan hal terpenting untuk dipenuhi. Generasi milenial atau generasi Y yang lahir dengan rentang tahun 1984 - 2000 (Home \& Strauss, 2018) merupakan generasi yang paling awal merasakan adanya revolusi industri 4.0.

Dekat dengan teknologi dan menganggap bahwa teknologi bukan hanya sekedar menjadi suatu alat komunikasi melainkan untuk dapat bergaul, berinteraksi maupun mencari informasi (W et al., 2020). Hal lain terjadi di negara China, pada tahun 2011 seorang remaja berusia 17 tahun rela menjual ginjalnya hanya demi membeli iPhone untuk menunjukkan kepada teman-temannya (Wartakota, 2020). Hal ini membuktikan bahwasannya generasi 
milenial mengedepankan citra diri, prestise dan sangat reaktif terhadap keadaan di lingkungan sekitarnya. Milenial akan melakukan segala cara untuk mendapatkan hal yang diinginkan. Milenial dinilai lebih mengedepankan kekayaan atau gaya hidupnya (Abraham \& Harrington, 2015).

Generasi milenial yang berada di Provinsi Bali, Kabupaten Badung merupakan target penelitian ini. Berdasarkan hasil data Badan Pusat Statistik tahun 2019, tingkat pertumbuhan ekonomi kabupaten Badung periode 2014 - 2019 berada diatas tingkat ekonomi Provinsi Bali bahkan Nasional dengan capaian angka 6\%. Hal ini membuktikan bahwa Kabupaten Badung telah cukup menjadi kabupaten yang unggul dalam sektor ekonominya. Namun, kabupaten Badung memiliki potensi perekonomian yang berbeda seperti sektor pariwisata hingga sektor pertanian di masing - masing daerahnya. Lalu, Apa yang menyebabkan milenial loyal terhadap penggunaan Brand Apple? Prestige or needs?

\section{Identifikasi Masalah}

Berdasarkan latar belakang masalah yang dijabarkan, maka dalam penelitian ini ingin mengetahui hal yang menyebabkan milenial loyal dalam meggunakan produk Apple. Produk Apple dijual dengan harga relatif mahal, namun tetap banyak konsumen membelinya. Prestige or needs?

\section{Rumusan Masalah} Apple?

Bagaimana loyalitas milenial di era Revolusi Industri 4.0 terhadap penggunaan brand

\section{LANDASAN TEORI}

\section{Perilaku Konsumen 4.0}

Di era Revolusi Industri 4.0, perilaku konsumen telah berubah dan berkembang dikarenakan generasi yang muncul adalah generasi yang peka terhadap teknologi. Perilaku konsumtif muncul di Indonesia, yang artinya konsumsi konsumen dipengaruhi oleh gaya hidup dimana bukan lagi hanya memenuhi kebutuhan namun berkaitan dengan keinginan. Umumnya hal ini wajar terjadi dikalangan remaja maupun dewasa muda yang disebut generasi milenial. Generasi milenial merupakan generasi yang lahir dengan rentang tahun 1982 - 2000 (Home \& Strauss, 2018). Berdasarkan buku yang digagas oleh (Rossanty et al., 2018) menunjukan perubahan konsumsi masyarakat dan gaya hidup yang berubah menjadi online atau digital basis. Seiring terbukanya informasi dalam masyarakat, perkembangan jaman juga mengubah pola pemikiran individu masyarakat, seperti lebih cenderung membutuhkan, ketepatan (accuracy), kecepatan (velocity), keamanan (safety), akses yang luas (accessibility) dan kenyamanan (comfortly) dalam mengkonsumsi suatu produk (Maharani, 2015).

\section{Loyalitas Konsumen}

Di era Industri Revolusi 4.0, telah menyebabkan pergeseran definisi dari loyalitas konsumen. Output customer path yang diharapkan perusahaan bukan lagi hanya purchase product (act), tetapi bagaimana konsumen yang sudah membeli produk tersebut bisa memengaruhi orang lain untuk ikut melakukan purchase dan menjadi existing customer kepada 
perusahaan (Dhiraj \& Ahmad, 2019). Terdapat tiga pendekatan dalam mengetahui loyalitas konsumen terhadap brand suatu produk (Rossanty et al., 2018), yaitu; Pendekatan Pengondisian Instrumental (Instrumental Conditioning). Pendekatan ini memandang bahwa seorang konsumen loyal terhadap suatu produk dapat terlihat dari jangka waktu yang lama dan konsistensi konsumen dalam menggunakan produk. Selanjutnya adalah pendekatan yang didasarkan oleh Teori Kognitif.

Dalam pendekatan ini loyalitas dinilai jika harga produk tersebut mengalami kenaikan, tetapi bukan menjadi suatu penghalang bagi konsumen untuk tetap membeli dan menggunakannya. Pendekatan terakhir adalah pendekatan Behavioural dimana loyalitas dalam pendekatan ini merupakan suatu perilaku konsumen yang melakukan pembelian suatu produk secara rutin dan bersifat kontinu.

\section{Kebutuhan Manusia}

Kebutuhan manusia terbagi menjadi lima tingkat atau hikarki menurut Abraham $\mathrm{H}$. Maslow (1943) dalam makalah 'A Theory of Human Motivation' (Subaidi, 2019) yaitu :

1. Kebutuhan Fisik (Phsycological Needs)

Hal mendasar yang dibutuhkan oleh manusia disebut dengan kebutuhan psikologi atau kebutuhan fisik. Seperti misalnya, kebutuhan akan oksigen, air hingga sandang, pangan dan papan.

2. Kebutuhan akan rasa aman (Safety Needs)

Tidak lebih penting dari itu, manusia tentu juga membutuhkan rasa aman yang berkontribusi besar pada perilakunya. Aman dalam melakukan dan menggunakan suatu produk misalnya.

3. Kebutuhan atas Cinta dan Kepemilikan (The Belongingness and Love Needs)

Cinta, penerimaan dan kepemilikan merupakan poin dasar dari kebutuhan sosial menurut Maslow.

4. Kebutuhan untuk dapat dihargai (The Esteem Needs)

Manusia juga membutuhkan rasa dalam dihargai, Maslow membaginya menjadi dua bagian. yaitu, lebih mengarah kedalam harga diri. Sedangkan yang kedua mengarah kepada sebuah penghargaan. Mendapatkan penghargaan diri atau prestise tertentu dan eksistensi nya diakui.

5. Kebutuhan aktualisasi diri (Self Actualization)

Perasaan manusia untuk dipenuhi atau perasaan yang hidup sesuai dengan potensi yang dimiliki. Kebutuhan ini, pada dasarnya berarti merasa bahwa manusia melakukan apa yang diyakini untuk dilakukan.

\section{METODE PENELITIAN}

Penelitian ini menggunakan pendekatan kualitatif. Dengan tahap awal mengumpulkan data, melakukan reduksi data, mendukung data dengan display data, diakhiri dengan penarikan kesimpulan dan juga rekomendasi. Setelah mengumpulkan data, selanjutnya peneliti melakukan uji keabsahan data yaitu dengan triangulasi sumber dan triangulasi teknik. Dimana 
peneliti membandingkan kembali hasil penelitian yang didapat dilapangan dengan hasil penelitian melalui dokumentasi yaitu selancar media sosial dengan sumber yang berbeda pula. Kabupaten Badung, Provinsi Bali menjadi tujuan riset ini. Badung yang terbagi menjadi 3 bagian memiliki tingkat ekonomi yang berbeda dikarenakan setiap bagian memiliki potensi yang berbeda pula.

Tahap awal dalam penelitian dengan melakukan literature review, yaitu dengan mencari informasi sebanyak - banyaknya terkait perilaku milenial dalam mengkonsumsi suatu produk. Melakukan dokumentasi yaitu berselancar dengan mencari data pendukung dalam media sosial, seperti Instagram, Facebook, Google maupun media sosial lainnya. Selanjutnya peneliti melakukan wawancara yaitu in-depth interview secara langsung dengan generasi milenial yang telah memenuhi kriteria peneliti. Yaitu informan dengan memiliki rentang tahun 1982 - 2000 yang termasuk kategori generasi milenial (Home \& Strauss, 2018). Menggunakan produk smartphone iPhone dan bertempat tinggal di Kabupaten Badung, Provinsi Bali. Berdasarkan hasil wawancara maka didapatkan masing - masing 2 informan dari masing masing bagian di Kabupaten Badung dengan total informan sebanyak 6 orang. Dalam proses penelitian, peneliti sudah menemukan data yang cukup, yang artinya pernyataan informan sudah bersifat jenuh atau monoton sehingga peneliti menyimpulkan untuk dapat melanjutkan analisis.

Maka berdasarkan syarat penelitian kualitatif, proses pengumpulan data dapat dihentikan apabila peneliti dirasa telah menemukan jawaban dari tujuan penelitian (Maulana, 2017). Dalam melakukan analisis, peneliti melakukan reduksi data dengan meringkas dan mengurangi hasil wawancara yang tidak penting atau kurang mendukung hasil penelitian. Peneliti berfokus untuk meringkas hal - hal penting untuk melengkapi data sehingga masalah penelitian dapat terjawab dengan tepat. Dalam penelitian ini, peneliti juga melakukan penyajian data dalam bentuk tabel dan gambar sehingga pembaca dapat mudah memahami hasil penelitian. Dalam arti lain, reduksi data berfokus kepada informasi - informasi penting yang peneliti dapatkan dalam melengkapi dan memperkuat hasil penelitian yang ditemukan.

Untuk mengetahui keabsahan data yang didapatkan saat melakukan pengumpulan data, penelitian ini juga menggunakan triangulasi sumber yaitu teknik uji yang dilakukan dari sumber yang berbeda. Triangulasi dilakukan dengan mengevaluasi data yang didapat dilapangan dengan dokumentasi yang dilakukan melalui sosial media. Untuk mengetahui hasil penelitian, selanjutnya peneliti melakukan penarikan kesimpulan atas hasil temuan.

\section{PEMBAHASAN}

Perkembangan jaman yang begitu pesat menyebabkan pesatnya pula perubahan dalam kehidupan manusia. Mulai berubahnya perilaku, cara pandang bahkan gaya hidup manusia saat ini. Munculnya industri revolusi 4.0 yang disebut dengan jaman digital ini, membuat perubahan tersebut sangat mudah terlihat dan terasa. Saat ini manusia terlena dengan kemudahan, aksesibilitas, kecepatan mendapat informasi bahkan semua hal yang instan untuk mendukung segala aktivitas manusia. Hal ini juga berdampak terhadap perilaku manusia yang dapat merubah pola pikir, gaya hidup dan berfokus kepada eksistensi diri, rasa bangga diri, sosial dan budaya serta etika dalam bermasyarakat atau bergaul (Widhiasthini, 2020).

Adanya transformasi perilaku konsumen dalam mengkonsumsi produk akibat perkembangan teknologi informasi. Cenderung berlebihan, karena saat ini konsumen dinilai telah mengesampingkan bahkan mengabaikan interaksi dengan sosial, kemampuan 
ekonominya dan manfaat dari suatu produk. Saat ini, konsumen lebih mementingkan citra diri, gengsi, gaya hidup bahkan berujung pencitraan yang dipengaruhi oleh perkembangan media sosial (Widhiasthini, 2020). Konsumen seakan berlomba - lomba untuk mendapat pengakuan dari lingkungan sosial bahkan melakukan segala cara untuk menjadi orang yang memiliki prestige yang tinggi dimata orang lain.

Selain kebutuhan fisik yang tentunya harus dipenuhi oleh manusia untuk bertahan hidup, kebutuhan psikologis seperti adanya rasa aman dalam menggunakan suatu produk kini menjadi faktor utama konsumen menggunakan produk tersebut (Hanum \& Hidayat, 2017). Terlebih lagi canggihnya teknologi yang memberikan dampak baik yang dapat sangat memudahkan manusia dalam melakukan sesuatu. Namun tidak usah dipungkiri bahwa teknologi juga menyebabkan dampak buruk pula dalam kehidupan manusia (Cahyono, 2016).

Seperti contohnya, banyak kasus yang terjadi dengan canggihnya teknologi yang ada. Banyak orang yang tidak bertanggung jawab seperti hacker bermunculan dan mengganggu kenyamanan konsumen dalam menggunakan teknologi. Kebutuhan akan rasa aman (safety needs) merupakan dasar bagi milenial dalam menggunakan iPhone. Menurut informan yang diwawancara, diakui bahwa iPhone adalah suatu produk smartphone yang memiliki tingkat keamanan yang tinggi dan user interface yang baik. Tingkat security iPhone dinilai ketat dan membantu konsumen dalam menjaga privasi dan sistem yang ada dalam iPhone.

Dengan sulitnya iPhone menerima data dari smartphone lainnya, ternyata justru ini terlihat sebagai salah satu hal yang positif. iPhone memiliki sistem tersendiri seperti aplikasi find my iphone yang dapat membantu konsumen dalam men-tracking keberadaan iPhone tersebut. Selain itu, konsumen pengguna iPhone dapat memblokir smartphone nya agar orang lain tidak bisa menggunakannya. Selain produk yang ditawarkan Apple bisa membuat konsumen aman dan nyaman, ternyata rasa untuk dihargai orang lain atau kebutuhan untuk dihargai (the esteem needs) menjadi faktor penentu pula. Dapat dihargai bahkan menjadi pusat perhatian di lingkungan masyarakat merupakan salah satu kebutuhan manusia yang saat ini menjadi suatu keharusan.

Didukung pula dengan kemajuan teknologi yang begitu pesat, mudahnya semua orang dalam mendapatkan informasi secara pribadi hingga mudahnya membagi kehidupan sehari hari disosial media. Milenial yang menjadi target informan dalam penelitian ini yang identik dengan kaum perkotaan yang kini memiliki karakteristik cenderung hedonis dan konsumtif, memikirkan prestige dalam mengkonsumsi suatu produk (Taufiq et al., 2018). iPhone sebagai salah satu produk yang menawarkan nilai prestis yang tinggi saat ini menjadi suatu produk yang diincar oleh milenial. Menjadi suatu produk yang dapat membantu milenial dalam bergaul, bahkan merasa kurang diperhatikan oleh orang lain jika tidak menggunakan iPhone. Seperti salah satu informan yang mengakui bahwa sebelum menggunakan iPhone, tidak pernah menjadi pusat perhatian teman - temannya.

Berbeda dengan setelah informan menggunakan iPhone, saat berkumpul dengan teman - temannya justru iPhone nya lah yang digunakan untuk sekedar memotret momen. Informan tersebut menyadari bahwa memang benar iPhone memberikan perubahan yang cukup signifikan dalam pergaulannya. Kebutuhan untuk dapat dihargai kini sudah seperti kebutuhan pokok manusia untuk dapat hidup di era digital (Patras et al., 2021). Tiga informan yang diwawancara merasa bahwa iPhone memberikan gengsi tinggi dalam pergaulannya, dengan harga yang eksklusif dan nama brand yang sudah cukup besar mampu mendukung konsumennya untuk mendapatkan prestise. Hal ini selaras dengan definisi konsumsi status 
yang dimana konsumsi dilakukan demi menaikan status dan citra diri dimata orang lain (Suminar \& Meiyuntari, 2016).

Konsumen rela membeli produk dengan harga yang mahal namun dirasa dapat menyampaikan gengsi maupun statusnya (Suryanadi, 2017). Rasa bangga dan percaya diri muncul karena menggunakan produk yang memiliki nilai prestis tinggi. Lingkungan pergaulan juga sangat mempengaruhi manusia dalam melakukan konsumsi dan membentuk persepsi. Berbeda dengan dua informan lainnya yang terlebih dulu berada dalam lingkungan pergaulan ekonomi yang terbilang 'mampu' dan menganggap bahwa iPhone merupakan produk yang biasa. Teknik triangulasi sumber dengan melakukan selancar melalui media sosial, melakukan dokumentasi dan mengumpulkan data untuk memperkuat fenomena ini.

Dalam dokumentasi yang dilakukan peneliti, ternyata terdapat milenial yang masih berpaku terhadap smartphone yang digunakan. Dokumentasi ditemukan dari media sosial TikTok yang memperlihatkan bahwa terdapat milenial yang menggambarkan bahwa akan mengganti smartphone Android nya dengan iPhone, seperti gambar 1.1 dibawah, dimana antusias terlihat ia rela membuat konten tersebut dari jauh hari dan membagikannya di sosial media untuk dilihat oleh followers dan untuk sekedar menunjukan rasa bahagianya.

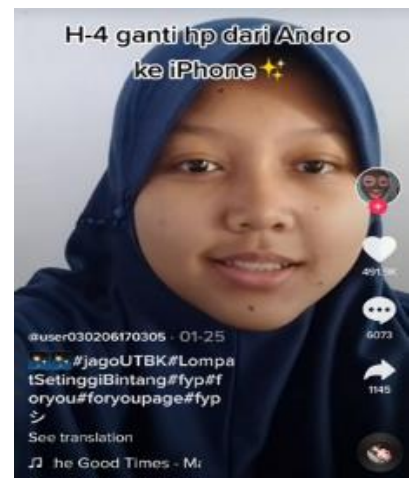

Gambar 1.1

Momen antusias Milenial dalam mengganti Smartphone

Hal yang sama juga terlihat dari seorang milenial pada gambar 1.2 yang terlihat bahagia saat akan mengganti iPhone yang digunakan sebelumnya dengan iPhone seri terbaru, padahal terlihat bahwa iPhone yang digunakan sebelumnya masih layak untuk digunakan, hal ini membuktikan bahwa milenial tersebut mempunyai loyalitas yang tinggi dan menunjukan gaya hidup prestige dan membagikannya ke sosial media untuk ditunjukan kepada followers nya.

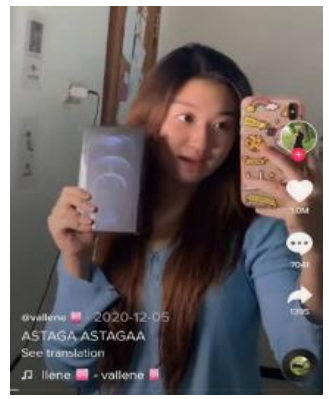

Gambar 1.2

Momen antusias Milenial dalam mengganti Smartphone 
Untuk dapat dihargai oleh orang lain memang disebutkan sebagai kebutuhan manusia. Namun, hal ini sangat tidak dibenarkan jika seseorang dapat melakukan perundungan atau bullying terhadap orang terdekatnya. Dalam melakukan dokumentasi, ditemukan pula bahwa seorang remaja milenial di-bully oleh sekumpulan teman dekatnya karena tidak menggunakan iPhone. Dalam video tersebut terlihat bahwa remaja yang hanya menggunakan Android merasa terpojok dan merasa kecil hati karena tidak membawa smartphone seperti teman - temannya. Seperti pada gambar 1.4, kasus ini membantu peneliti dalam memperkuat fenomena yang terjadi pada milenial, bahwa ternyata ada beberapa milenial yang mementingkan prestige dan ingin terlihat keren didalam pergaulannya bahkan sampai mem-bully teman dekatnya.

Hal itu secara tidak langsung juga dapat menyebabkan psikologis yang ter-bully merasa terganggu. Dalam hal ini dibuktikan bahwa prestige mempengaruhi seseorang dalam menggunakan sesuatu di era saat ini.

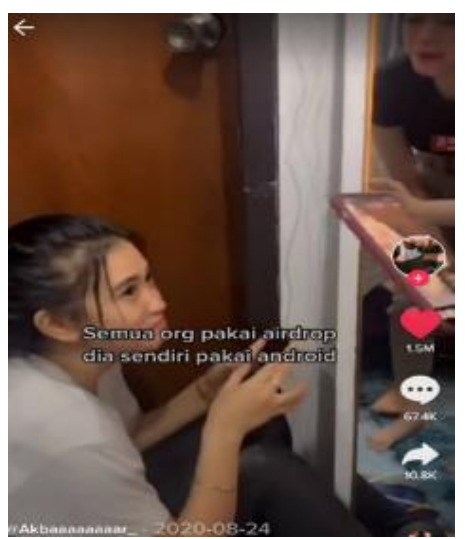

Gambar 1.3

Perundungan yang dilakukan oleh orang sekitar

Dan merasa dihargai juga menjadi tujuan milenial dalam menggunakan suatu produk. Peneliti dalam hal ini juga menemukan fenomena yang dapat memperkuat bahwa prestige atau rasa ingin dihargai merupakan suatu tujuan utama milenial menggunakan iPhone. Dalam sebuah video yang ditemukan menunjukam bahwa milenial tersebut menggunakan iPhone hanya untuk kebutuhan konten saja. Dalam penelusuran dokumentasi yang dilakukan oleh peneliti, memang milenial tersebut termasuk kedalam milenial dengan ekonomi atas. Dalam fenomena itu, memang benar dibuktikan bahwa perilaku milenial saat ini bersifat konsumtif, konsumen bukan lagi menggunakan produk berdasarkan kebutuhannya, namun berdasarkan keinginan dan menggunakannya dengan tiada batas (Hidayatullah et al., 2018).

Hal ini juga dapat terjadi karena perubahan jaman yang begitu pesat, dengan munculnya media sosial yang membuat milenial berlomba - lomba untuk membuat konten dan mendapat perhatian dan ingin merasa dihargai oleh orang lain (Sakinaputri \& Sartika, n.d., 2016). Selanjutnya adalah kebutuhan aktualisasi diri, kebutuhan ini akan dinyatakan benar - benar terpenuhi jika ke-4 kebutuhan tersebut sudah dipenuhi. Dalam hal ini, seorang milenial menggunakan produk iPhone sebagai motivasi dalam pengembangan diri sendiri maupun sebaliknya. Menggunakan iPhone sebagai apresiasi diri terhadap potensi atau pencapaian yang dimiliki (Hidayatullah et al., 2018).

Dalam penelitian ini, hanya terdapat satu informan saja yang menggunakan iPhone sebagai kebutuhan aktualisasi diri. Memanfaatkan potensi yang dimiliki dan menggunakan produk iPhone sebagai motivasi dalam pencapaiannya. Informan tersebut membeli produk 
iPhone karena ingin mengapresiasi dirinya karena telah memenangkan suatu perlombaan. Bahkan rela menghabiskan hadiah tersebut hanya untuk membeli iPhone. Informan menyebutkan bahwa suatu hal yang didapatkan dengan adanya perjuangan, tentu akan lebih dapat dijaga dengan baik pula.

Dalam berselancar dimedia sosial, peneliti juga menemukan milenial yang sama. Dengan mendapatkan iPhone sebagai apresiasi diri atas kerja keras dan pencapaiannya sebagai seorang influencer. Seperti gambar 1.5, milenial tersebut merasa bangga terhadap sesuatu yang dapat tercapai dengan hasil keringatnya.

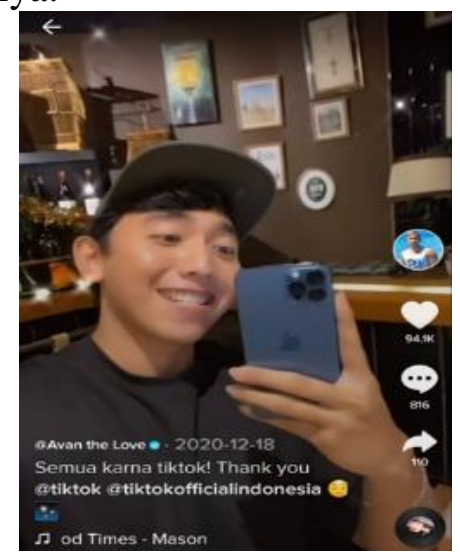

Gambar 1.4

Influencer mengapresiasi pencapaian diri

Maka, dapat disimpulkan bahwa milenial menjadikan potensi serta kemampuan dirinya bukan untuk sekedar mengembangkan diri, melainkan memenuhi kebutuhan dengan cara menghargai dan mengapresiasi diri sendiri. Terlepas dari membeli produk karena alasan prestis atau status sosial namun dalam hal ini patut diapresiasi bahwa dengan menghargai pencapaian diri sendiri merupakan suatu hal yang tidak boleh untuk dilupakan. Loyalitas merupakan satu tolok ukur bagi keberlangsungan hidup perusahaan. Setiap perusahaan memiliki tujuan berbeda - beda dalam menawarkan produk atau jasa kepada konsumennya.

Namun, memiliki konsumen yang loyal terhadap perusahaan merupakan satu tujuan tertinggi perusahaan. Dalam tahap ini perusahaan sudah mencapai dalam tahap puncak, dimana produk dan jasanya telah diketahui lalu digunakan bahkan terjadi repeat use dari konsumen yang menggunakannya. Loyalitas juga dapat dikatakan sebagai kekuatan hubungan antara konsumen dengan merek, jasa, toko bahkan pemasok dan pembelian secara berulang (Steve Engelhart et al., n.d., 2018). Dalam penelitian ini, peneliti menggunakan acuan teori terkait tiga pendekatan dalam mengetahui loyalitas milenial yang dikemukakan oleh (Rossanty et al., 2018). Yaitu Pendekatan Pengondisian Instrumental (Instrumental Conditioning) yang memandang bahwa seorang konsumen loyal terhadap suatu produk dapat terlihat dari jangka waktu yang lama dan konsistensi konsumen dalam menggunakan produk.

Lalu Pendekatan yang didasarkan oleh Teori Kognitif dimana loyalitas dinilai jika harga produk tersebut mengalami kenaikan, tetapi bukan menjadi suatu penghalang bagi konsumen untuk tetap membeli dan menggunakannya. Dan terakhir adalah Pendekatan Behavioural, loyalitas dalam pendekatan ini merupakan suatu perilaku konsumen yang melakukan pembelian suatu produk secara rutin dan bersifat kontinu. Berdasarkan wawancara yang dilakukan peneliti, bahwa sebanyak 5 informan termasuk loyal terhadap iPhone karena telah memenuhi kriteria loyalitas tersebut. Informan menggunakan iPhone dalam jangka waktu yang terbilang lama, bersifat kontinu dan tidak ingin melakukan switch brand karena telah 
merasa nyaman menggunakan produk iPhone tersebut. Selain kenyamanan yang ditawarkan, iPhone juga memberikan nilai prestis terhadap konsumennya.

Terlebih lagi, milenial merupakan generasi yang mengikuti mode setiap saat. Dan cenderung mengutamakan penampilan agar terlihat lebih keren dan dapat dihargai oleh lingkungan sekitar. Namun dalam hal ini, peneliti mendapatkan kesimpulan bahwa iPhone masih memiliki target market menengah - keatas. Dibuktikan bahwa terdapat 3 informan yang masih berpikir dua kali dalam melakukan pembelian iPhone kedalam seri terbaru. Walaupun adanya keinginan dan niat untuk mengikuti trend yang ada, namun karena ekonomi yang berkecukupan maka informan tersebut mengurunkan niat dan masih lebih mementingkan kebutuhan primernya.

Dengan berselancar kembali untuk memperkuat temuan penelitian, terdapat 3 video yang berasal dari media sosial TikTok yang memperlihatkan bahwa konsumen Apple tersebut dapat dikatakan loyal. Tercermin bahwa milenial tidak hanya menggunakan iPhone sebagai smartphone nya saja melainkan hampir seluruh lini produk Apple, seperti, macbook, airpods, iPad, iPod dan Apple Watch. Terlihat pula bahwa terdapat banyak koleksi iPhone seri terbaru yang tentu di upload pada sosial media, dimana iPhone tersebut masih terlihat layak untuk digunakan. Hal ini juga menunjukan bahwa milenial diatas termasuk kedalam kategori konsumen yang konsumtif. Loyalitas tentu bukan hanya dilihat dari seberapa sering konsumen menggunakan produknya, bukan lagi hanya mengabaikan harga produk yang dimiliki, bukan hanya jangka waktu dalam menggunakan produk tersebut.

Namun dapat dilihat pula dari fanatisme seorang konsumen dalam menggunakan brand produk yang digunakan. Tidak dapat dipungkiri Apple kini sudah mampu menguasai pangsa pasar milenial dan tetap mempertahankan konsumen dikarenakan prestige value yang ditawarkan oleh Apple. Berdasarkan hasil temuan, peneliti menyimpulkan bagaimana perilaku konsumen di era revolusi industri 4.0 ini terkhusus kepada generasi milenial. Dengan kemajuan dan kemudahan di era revolusi industri 4.0 memudahkan konsumen pula dalam melakukan akses melalui media online (Rosita Dewi, 2020). Konsumen saat ini cenderung konsumtif dan menjadi follower atau mudah dipengaruhi oleh lingkungan. (Maheswari \& Gorda, 2019).

Berdasarkan buku yang ditulis oleh (Mix Marcomm, 2018) karakter generasi milenial adalah digital literacy, konsumtif, menabung untuk sesuatu yang diimpikan, menggunakan media sosial sebagai wadah komunikasi, generasi milenial semakin merasa sukses jika membagikan momen - momen di media sosial dan memiliki karakter FOMO (Fear of Missing Out). Faktor budaya juga menjadi salah satu faktor yang menyebabkan konsumen dalam menggunakan suatu produk atau jasa. Konsumen 4.0 cenderung mengikuti perkembangan trend saat ini yang terjadi, fenomena trend kekinian yang saat ini sudah lazim di lingkungan (Widhiasthini, 2020). Faktor sosial yaitu rasa ingin lebih dihargai oleh orang lain kini menjadi karakter dari generasi milenial. Dengan menggunakan produk yang memberikan prestige value membuat milenial mengkonsumsi suatu produk.

Konsumen saat ini saling ingin memperlihatkan kelas sosialnya yang berbeda di komunitasnya. Seperti yang dinyatakan oleh (Subawa, 2016) konsumsi suatu produk dapat dipengaruhi oleh status sosial, life style, psikologis dan prestise. Gaya hidup saat ini tidak terlepas dari hedonisme yang terjadi akibat perkembangan jaman. Konsumen khususnya milenial saat ini lebih cenderung memenuhi keinginan untuk dapat bergaul dalam lingkungan sosial. Bahkan hingga mengesampingkan kebutuhan primer dalam kehidupan sehari - hari. Masifnya perkembangan jaman menyebabkan transformasi konsumsi berubah dan bervariasi. 
Gaya hidup hedonis dilakukan demi mendapatkan suatu gelar prestise dan membagikan di sosial media untuk sekedar mendapatkan pengakuan.

\section{KESIMPULAN DAN SARAN}

\section{KESIMPULAN}

Transformasi perilaku konsumen di era 4.0 terjadi karena perkembangan jaman yang begitu pesat. Karakter konsumen saat ini termasuk konsumtif, mengikuti perkembangan trend, memperhatikan prestise dan gaya hidup hedonisme, merasa puas membagikan momen momen di media online. Tidak suka tersaingi dan ingin menjadi berbeda dalam komunitasnya. Menjadi follower atau mudah dipengaruhi oleh lingkungan. Namun tetap memiliki alasan rasional dalam menggunakan suatu produk. Kebutuhan akan rasa aman (Safety Needs) konsumen dalam mengkonsumsi suatu produk merupakan faktor dan alasan penting konsumsi milenial di era industri 4.0.

Selain pemenuhan kebutuhan primer, kebutuhan psikologis seperti kebutuhan untuk dapat dihargai (The Esteem Needs) merupakan suatu hal yang kini menjadi lazim yang terjadi di era industri 4.0. Konsumen khususnya milenial mengedepankan prestige dalam menggunakan suatu produk untuk dapat bergaul dan lebih dihargai oleh lingkungan sekitar. Generasi milenial adalah generasi yang rela menabung dan melakukan segala cara termasuk memanfaatkan potensi diri untuk memenuhi keinginannya. Sejalan dengan Kebutuhan aktualisasi diri (Self Actualization) yang dicanangkan oleh Abraham Maslow, bahwa motivasi dalam diri dapat menjadi acuan milenial untuk mendapatkan apa yang diinginkan. Loyalitas konsumen milenial menggunakan produk Apple telah dibuktikan bahwa informan menggunakan iPhone dalam jangka waktu lama, bersifat kontinu yang dibuktikan dari perpindahan seri iPhone lama hingga terbaru. Namun masih ada batasan bagi milenial yang belum memiliki ekonomi yang cukup, disebutkan bahwa harga masih menjadi penghalang milenial dalam loyal terhadap iPhone.

\section{SARAN}

Apple menjadi terkenal dan melekat dalam benak konsumen karena branding yang diciptakan saat awal Apple memproduksi suatu produk. Apple mampu melihat pangsa pasar, mampu membaca peluang, mampu memahami karakteristik dan intensi konsumen sehingga apa yang diminati oleh konsumen mampu terpenuhi. Saat ini perusahaan harus mampu mengetahui persepsi dan keinginan konsumen yang dapat diadopsi dikehidupannya. Perusahaan dituntut mampu dalam melakukan proses yang lebih baik untuk mengetahui kebutuhan pasar. Perusahaan harus mampu memberikan produk yang memiliki nilai yang berbeda dari perusahaan lainnya. Sehingga dapat menentukan positioning yang baik dalam benak konsumen. Masifnya perkembangan jaman dan kemudahan yang dapat dilakukan menuntut perusahaan untuk memberikan kenyamanan kepada konsumen seperti keamanan dan kemudahan dalam menciptakan suatu produk atau jasa. 


\section{DAFTAR PUSTAKA}

Abraham, R., \& Harrington, C. 2015. Consumption Patterns of the Millenial Generational Cohort. Modern Economy.

Cahyono, A. S. 2016. 79-148-1-Sm (1). Pengaruh Media Sosial Terhadap Perubahan Sosial Masyarakat Di Indonesia, Jurnal Unita. 9(1), 140-157. (Online) ,(http://jurnalunita.org/index.php/publiciana/article/view/79, diakses 2 Mei 2021).

Dhiraj, A., \& Ahmad, S. 2019. WOW! Engage, Experience and Enjoy Marketing 4.0. Communication Today.

Ferrinadewi, E. 2016. Pengaruh Nilai-Nilai Hedonis dan Konsep DiriTerhadap Keputusan Pembelian dan Dampaknya Pada Loyalitas Merekdi Surabaya ( studi pada pembelian barang mewah ). E-Journal Manajemen Kinerja, 2(2), 1-11. (Online). https://jurnal.narotama.ac.id/index.php/manajemenkinerja/article/view/203, diakses 2 Mei 2021.

Hanum, Z., \& Hidayat, S. 2017. Faktor - faktor yang mempengaruhi perilaku konsumen dalam keputusan pembelian sepatu merek nike di kota medan. Jurnal Bisnis Administrasi, 06(01), 37-43. (Online), (https://core.ac.uk/download/pdf/235003954.pdf, diakses 28 April 2021)

Home, N., \& Strauss, W. 2018. Millenials Rising: The Next Generation. Small Business and the City.

Maharani, N. 2015. Proses Pengambilan Keputusan Pembelian Konsumen Terhadap Produk Iphone Di Bandung. Jurnal Manajemen Dan Bisnis (Performa), 12(1), 59-75. (Online), (https://elearning2.unisba.ac.id/index.php/performa/article/view/3043, diakses 20 Juni 2021)

Maheswari, K. I., \& Gorda, A. A. N. O. S. 2019. Consumer Behavior in the Era of Industrial Revolution 4.0. Russian Journal of Agricultural and Socio-Economic Sciences, 94(10), 152-157. (Online), (https://doaj.org/article/a3cf62757e3b4e35a5edbbfabf6ce5da, diakses 20 Juni 2021)

Mahyuddin. 2017. Social Climber dan Budaya Pamer: Paradoks Gaya Hidup Masyarakat. Kajian Islam Interdisipliner.

Maulana, M. S. R. 2017. Pemaparan Metode Penelitian Kualitatif. Ekp, 13(3), 1576-1580.

Mix Marcomm. 2018. Millenials. In Fantasious x Lovable (Issue Millenials.).

Patras, Y., Harapan, S. K., Dwikristanto, Y. P., Studi, P., Ekonomi, P., \& Harapan, U. P. 2021. Dampak Penggunaan Gadget Dan Internet Terhadap Sikap Saling Menghargai dalam Pembelajaran Akuntansi. 1(1), 1-13. UPH Academic Journal. (Online), (https://ojs.uph.edu/index.php/KAIROS/article/view/3159, diakses 20 Mei 2021)

Rosita Dewi, M. S. 2020. Komunikasi Sosial Di Era Industri 4.0 (Studi Pada Etika Komunikasi Remaja Perempuan Melalui Media Sosial di Era Industri 4.0). Research Fair Unisri, 4(1), 65-77. (Online), (http://ejurnal.unisri.ac.id/index.php/rsfu/article/view/3388, diakses 13 
April 2021).

Rossanty, Y., Nasution, muhammad dharma tuah, \& Ario, F. 2018. Consumer Behaviour in Era Millennial. In lembaga penelitian dan penulisan ilmiah AQLI.

Sakinaputri, R. M., \& Sartika, D. 2016. Hubungan antara Locus Of Control dan Gaya Hidup Hedonis pada Anggota Organisasi Growth and Youth ( Studi pada Remaja yang Berstatus Pelajar SMA ). Jurnal Unisba. 950-955. (Online), (http://karyailmiah.unisba.ac.id/index.php/psikologi/article/view/4605, diakses 12 April 2021)

Steve Engelhart, A. M., Massie, J., \& Wenas, R. 2018. Pengaruh Nilai Pelanggan Dan Kualitas Pelayanan Terhadap Kepuasan Dampaknya Terhadap Loyalitas Nasabah.

Subaidi, S. M. 2019. Kebutuhan Manusia dalam Pemikiran Abraham Maslow. Al-Mazahib, 7(1), 17-33. Jurnal Pemikiran Hukum. (Online), (http://ejournal.uinsuka.ac.id/syariah/almazahib/article/view/1877, diakses 11 April 2021).

Subawa, N. S. 2016. Prestige Pricing Strategy as A Symbol of Social Class on Perfume Products. Jurnal Bisnis Dan Manajemen, 17(1), 13-21. (Online), (http://journal.feb.unpad.ac.id/index.php/jbm/article/view/2, diakses 13 April 2021).

Suminar, E., \& Meiyuntari, T. 2016. Konsep Diri, Konformitas dan Perilaku Konsumtif pada Remaja. Persona:Jurnal Psikologi Indonesia, 4(02). (Online), (http://jurnal.untagsby.ac.id/index.php/persona/article/view/556, diakses 15 April 2021)

Tata Rini, Y. 2019. Mengurai Peta Jalan Akuntansi Era Industri 4.0. Referensi : Jurnal Ilmu Manajemen Dan Akuntansi, 7(1), $58 . \quad$ (Online), (https://jurnal.unitri.ac.id/index.php/refrensi/article/view/1339, diakses 20 Juni 2021)

Taufiq, Adhitya Rahmat. Mandasari, Andina Eka. Romdani, A. 2018. Analisis Faktor-Faktor Pembentuk Konsumsi. Jurnal Ekonomi Manajemen, 4(2), 143-149. (Online), (http://jurnal.unsil.ac.id/index.php/jem/article/view/704, diakses 15 Mei 2021)

Universitas Sebelas Maret. Jurusan Manajemen., A., \& Suryanadi, P. 2017. Fungsi Merek Berupa Jaminan. Fokus Manajerial, 13(1). (Online), (https://jurnal.uns.ac.id/fokusmanajerial/article/view/11366, diakses 13 Mei 2021)

W, R. W. A., Poluakan, M. V., Dikayuana, D., Wibowo, H., \& Raharjo, S. T. 2020. Potret Generasi Milenial Pada Era Revolusi Industri 4.0. Focus : Jurnal Pekerjaan Sosial, 2(2), 187. (Online), (https://jurnal.unpad.ac.id/focus/article/view/26241/0, diakses 10 April 2021)

Widhiasthini, N. W. 2020. Konsumen Era Revolusi. 